\title{
Recurrent Childhood Ependymoma
}

National Cancer Institute

\section{Source}

National Cancer Institute. Recurrent Childhood Ependymoma. NCI Thesaurus. Code C8579.

The reemergence of ependymoma in childhood after a period of remission. 